\title{
ESTIMATION AND MAPPING OF INFILTRATION BASED ON A MULTI-CRITERIA ANALYSIS
}

DOI: https://doi.org/10.18509/AGB.2017.03

UDC: 556.38:[528.88:004.6

\author{
Yamina Benkesmia ${ }^{1}$, Nadjla Bentekhici ${ }^{1}$, Lahcen Wahib Kebir ${ }^{1}$ \\ ${ }^{1}$ Centre des Techniques Spatiales, Arzew, Algeria \\ Corresponding author: yaminabenkesmia@gmail.com
}

Submitted: January 2017, Accepted: April 2017, Published: August 2017

\begin{abstract}
Groundwater circulating in aquifer systems comes mainly from water precipitation infiltration. This infiltration, which can be evaluated by different methods (water balance, hydrodynamic or hydrochemical), is systematically distributed throughout the entire watershed or permeable zones.

The main objective of this work is to estimate the recharge rate of the aquifers by using the distribution of factors related to the infiltration on the surfaces such the lithological nature of the soil/sub-soil, land use, vegetation cover and slope.

The used approach is a cartographic one and it is based on different data related to the considered factors. This approach uses remote sensing data and geographic information system.

The obtained result is a synthesis map of the recharge potential in the Sidi Bel Abbes plain in northwestern Algeria. This map is divided into four zones according to the recharge rate.
\end{abstract}

Key words: infiltration, recharge rate, mapping, GIS, remote sensing data;

\section{Introduction}

Since 1980, many approaches on recharge estimation are reported in the literature. The development of these methods is mainly related to the limitations of conventional ones that are successfully used in temperate zones and unsuitable for semi-arid and arid regions where aquifer recharge is generally indirect/local [6,2] in [1] .

The estimation of the recharge rate in these regions is of particular interest in any quantification and management study in order to ensure the sustainability of this resource, which is becoming increasingly rare.

In this context, the overexploitation and degradation of the quality of groundwater in the Sid Bel Abbes plain require interventions, sometimes very urgent to preserve these resources.

\section{Study area}

With an area of $1,120 \mathrm{Km}^{2}$, the Sidi Bel Abbes plain constitutes the lowest part of the area of the Mekarra watershed (Fig. 1). This region is considered as the most important one in northwest of Algeria. The Plio-quaternary formations fill the great alluvial valley of Sidi Bel Abbes that constitutes the most exploited aquifer in the considered region.

Faced with the needs of populations, industries and agriculture, this alluvial aquifer has been intensively exploited in recent years, where rainfall is about $60 \mathrm{hm}^{3} /$ year and the dominant climate is semi-arid. The estimation of the infiltration rate and/or the recharge rate towards the aquifers becomes necessary to orient the exploitation towards the general development of the water resources. 


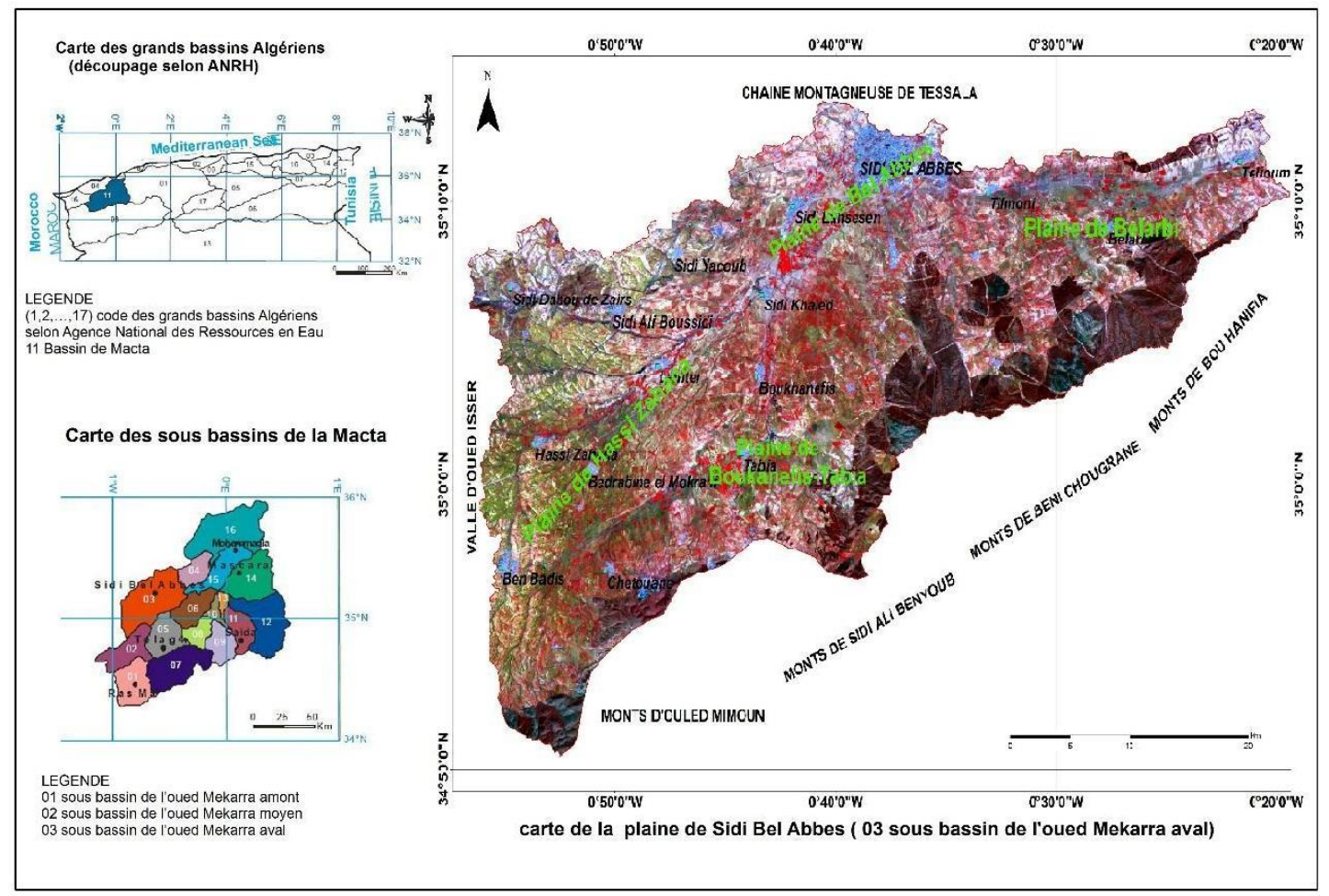

Figure 1: Geographical location of the study area

\section{Data used}

For the estimation of the recharge rate at the study area, multisource remote sensing and exogenous data are used.

The used remote sensing data are from the Landsat 8 sensor taken in March 2016 and the ASTER digital terrain model. These data are characterized by $30 \mathrm{~m}$ spatial resolution.

Exogenous data include a hydrogeological map at the scale of $1 / 100,000$ [9], a map of agricultural soils at the scale of 1/100,000 [3] and climate data.

The processing of the remote sensing data is carried out using the ENVI software, while thematic maps are crossed by using geographic information system.

\section{Methodology adopted}

The method applied for mapping areas affected by infiltration, which corresponds to the recharge potential zones in the Sid Bel Abbes plain, is based on a multi-criterion approach.

This method must go through four essential steps, such as "definition, classification and evaluation of the criteria rating, weights determination, weighting and combination of criteria".

\section{Definition of criteria:}

In this step, criteria that serve to establish the map of the recharge potential zones are defined. These criteria are the slope, the soil, the lithology, the drainage, vegetation cover and the land use.

Slope is obtained from digital terrain model. This criterion allows identifying zones with weak slope indicating zones favorable to the good conditions of infiltration.

Drainage is obtained by a set of processing made on the digital terrain model, where from arises the map of drainage density by decomposition in sub-basin realized according to the principle of Horton [5].

With:

$$
D d=\frac{\sum L i}{2 A}
$$

$\mathrm{D}_{\mathrm{d}}$ : drainage density $\left[\mathrm{km} / \mathrm{km}^{2}\right]$;

$\mathrm{L}_{\mathrm{i}}$ : Length of river $[\mathrm{km}]$;

A : watershed area $\left[\mathrm{km}^{2}\right]$. 
Lithology is extracted from the hydrogeological map of the Sidi bel Abbes plain [9] .The geological units are collected in four chaps of grounds according to their hydrogeological behavior by basing itself on the works of Sourisseau and the Agency National of Water resources in 1973, namely:

- Karstic grounds, which present a big permeability, they correspond to formations of jurassico-cretaceous age of the mounts of Sidi Ali Benyoub and some limestones of Eocene age of Sid Ali Boussidé.

- Plio-quaternary alluvial formations and Aptian limestones, these formations establish permeable horizons.

- Weak formations in water resources are the Pliocene sandstones of the Tenira forest, the valangian limestone, and the gray marls with some banks of conglomerates and sandstones of the Olig-Miocene.

- The impermeable substratum of the alluvial groundwater corresponds to marls of Miocene age.

Soil represents the grounds superficial; this map elaborated from the digitization of the map of the agricultural soils of Sidi Bel Abbes plain [3]. Depending on the texture of the soils, we have clay-sandy soils with "ferralitic

brown soils and ferralitic red soils"; soils with balanced textures, "calcareous brown soils, rendzines, colluvial soils, alluvial soils" and finally soils with textures not studied "forest soils".

Vegetation cover and land use are obtained from the supervised classification using the maximum likelihood algorithm on the Land- sat 8 image. It allows a classification according to chap and the intensity of vegetation cover; Class 01 "Forest and / or scrub", Class 02 "Agricultural area", Class 03 "Fire, degraded land, sparse vegetation" and Class 04 "Water plans, urban, bare soil".

\section{Classification and evaluation of the cri- teria rating:}

To facilitate the performance, every identified criterion is subdivided into classes varying from very low degree to the very high degree based on the beaches ranges of the criteria variation [4].

The importance of every class estimated by rating that varies according to its influence on the infiltration. Therefore, all the criteria are classified according to the same rating ladder with the exception of the criterion "slope" which has an evaluation of the ratings independent of the other criteria, it is due to the slope which has an inverse relation with the infiltration; more the slope is low more the infiltration is very important (Table 1) .

In these investigations, weight determination bases on the analysis of the relational effects inter-parameterized: one point (1pt) assigns for each major effect, and a half point $(0.5$ pt) for each minor effect. The weight of each factor will then be equal to the sum of effects that they exercise on the others $[7,8]$. For instance, the drainage affects all factors, which result in a weight of four for this parameter.

\section{Weights determination:}

The weight of influence of the factors expressed in points as follows:

$\begin{array}{llll}\text { Drainage: } & 4 \text { major } & =(4 \times 1) & =4 \mathrm{pts} \\ \text { Vegetation cover-land use: } & 1 \text { major }+2 \text { minor } & =(1 \times 1)+(2 \times 0.5) & =2 \mathrm{pts} \\ \text { Slope: } & 3 \text { major } & =(3 \times 1) & =3 \mathrm{pts} \\ \text { Lithology: } & 4 \text { major } & =(4 \times 1) & =4 \mathrm{pts} \\ \text { Soil: } & 2 \text { major }+2 \text { minor } & =(2 \times 1)+(2 \times 0.5) & =3 \mathrm{pts}\end{array}$




\section{Weighting and combination of criteria (determination of infiltration index):}

The multi-criteria analysis requires the weighting of the elements according to the importance of each one in the realization of the treated subject. In this work, the role of each of these parameters in infiltration is weighted, evaluated and expressed under the term "infiltration index" as well as its contribution rate.

The "recharge potential" in a given area corresponds to the results of the indices of all parameters taken into account.

In estimate the contribution of each factor in the potential recharge, its weight and rating have been integrates, as shown in Table 01:

Table 1: Evaluation of the infiltration indices and the contribution rate

of the parameters on the recharge

\begin{tabular}{|c|c|c|c|c|c|c|}
\hline factor & Classes & Domaine of effet & 里气 & $\frac{5}{50}$ & 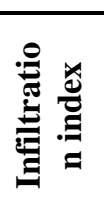 & 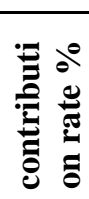 \\
\hline \multirow{4}{*}{ Lithology } & Very high & Karstic grounds & 10 & \multirow{4}{*}{4} & \multirow{4}{*}{90} & \multirow{4}{*}{37} \\
\hline & High & $\begin{array}{l}\text { Alluvionnaires formations } \\
\text { Cracked limestones }\end{array}$ & 8 & & & \\
\hline & Moderate & $\begin{array}{c}\text { Formations have lean to low } \\
\text { water resources }\end{array}$ & 3,5 & & & \\
\hline & Very low & substratum of alluvial grounwater & 1 & & & \\
\hline \multirow{3}{*}{ Soil } & Moderate-high & Forest soils & 6,5 & \multirow{3}{*}{3} & \multirow{3}{*}{40.5} & \multirow{3}{*}{17} \\
\hline & Moderate & $\begin{array}{c}\text { Soils with a balanced texture ( } \\
\text { limono-sandy and Limono-clay- } \\
\text { sandy ) }\end{array}$ & 5 & & & \\
\hline & $\overline{\text { Low }}$ & Soils with clay-sandy texture & 2 & & & \\
\hline \multirow{4}{*}{$\begin{array}{l}\text { Vegetation } \\
\text { cover and } \\
\text { land used }\end{array}$} & High & Forest and / or scrub & 8 & \multirow{4}{*}{2} & \multirow{4}{*}{32} & \multirow{4}{*}{13} \\
\hline & Moderate & Agricultural sector & 5 & & & \\
\hline & Low & $\begin{array}{l}\text { Fire, degraded land, sparse } \\
\text { vegetation }\end{array}$ & 2 & & & \\
\hline & Very low & Water plans, urban, bare soil & 1 & & & \\
\hline \multirow{4}{*}{ Slope } & Very high & $>25 \%$ & 1 & \multirow{4}{*}{3} & \multirow{4}{*}{34.5} & \multirow{4}{*}{14} \\
\hline & High & $12.5-25 \%$ & 2 & & & \\
\hline & Moderate & $3-12.5 \%$ & 3.5 & & & \\
\hline & Low & $0-3 \%$ & 5 & & & \\
\hline \multirow{4}{*}{ Drainage } & Moderate & $\overline{\mathrm{Dd}>2}$ & 5 & \multirow{4}{*}{4} & \multirow{4}{*}{46} & \multirow{4}{*}{19} \\
\hline & Moderate -low & $1.5<\mathrm{Dd}<2$ & 3.5 & & & \\
\hline & low & $1<\mathrm{Dd}<1.5$ & 2 & & & \\
\hline & \begin{tabular}{|l|} 
Very low \\
\end{tabular} & $\overline{\mathrm{Dd}}<1$ & 1 & & & \\
\hline
\end{tabular}

\section{Results and discussion}

The initiative proposed in this work took place in two stages, the first stage consists in the construction of the basis of the data by elaboration of five thematic maps (slope, lithology, soil, drainage density, vegetation cover and use land), and who by combination will give in the second stage of potential recharge (Fig. 2).

\section{Establishment of the synthesis map}

The integration and the crossing of the main factors, which are related to infiltration, into a geographic information system enabled the establishment of a recharge potential map. This map reveals the major areas of infiltration in the Sidi Bel Abbes plain (Fig. 3). Thus, four (4) descriptive levels have been highlighted. The projection of these levels on the scale proposed by FAO in 1967 [4,7,8], shows similar values recharge rate classes from low to very high recharge potential, grouped in Table 2 following: 
Table 2: Recharge rate classification according to the FAO (1967)

\begin{tabular}{|l|r|r|r|r|r|}
\hline Recharge Classes & \multicolumn{1}{|c|}{ Very High } & \multicolumn{1}{c|}{ High } & \multicolumn{1}{c|}{ Moderate } & \multicolumn{1}{c|}{ Low } & \multicolumn{1}{l|}{ Very } \\
\hline FAO (1967) & $45-50 \%$ & $30-35 \%$ & $10-20 \%$ & $5-10 \%$ & $<5 \%$ \\
\hline Deteremined Rate & $\mathrm{D}$ & $\mathrm{D}$ & $\mathrm{D}$ & $\mathrm{D}$ & ND \\
\hline Taux Moyen & $47.5 \%$ & $32.5 \%$ & $15 \%$ & $7.5 \%$ & $/$ \\
\hline
\end{tabular}

D: Determined; ND: No Determined

These classes show optimistic values as potential recharge.

Highly recharged areas observed at the Jurassic-Cretaceous karst outcrops of the Sidi Ali Benyoub Mountains and at the level of the drainage channels that are located around the towns of Chetouenne, Belarbi and Sidi khaled.

The high-recharge zones characterize agricultural soils with the balanced-textured at the Belarbi Plain, the Boukhanfiss-Tabia Plain, the Bel Abbes Plain, the Eocene limestones of Sidi Ali Boussidi and the limestones of the Aptien Age.

The medium-recharge zones are located around the town of Bel Abbes, at the level of the Hassi Zahana plain, which covered by clay-sandy soils, and at level of the Tenira dome forests.

Low-recharge zones encountered in the Miocene formations that constitute substratum of the alluvial groundwater table.

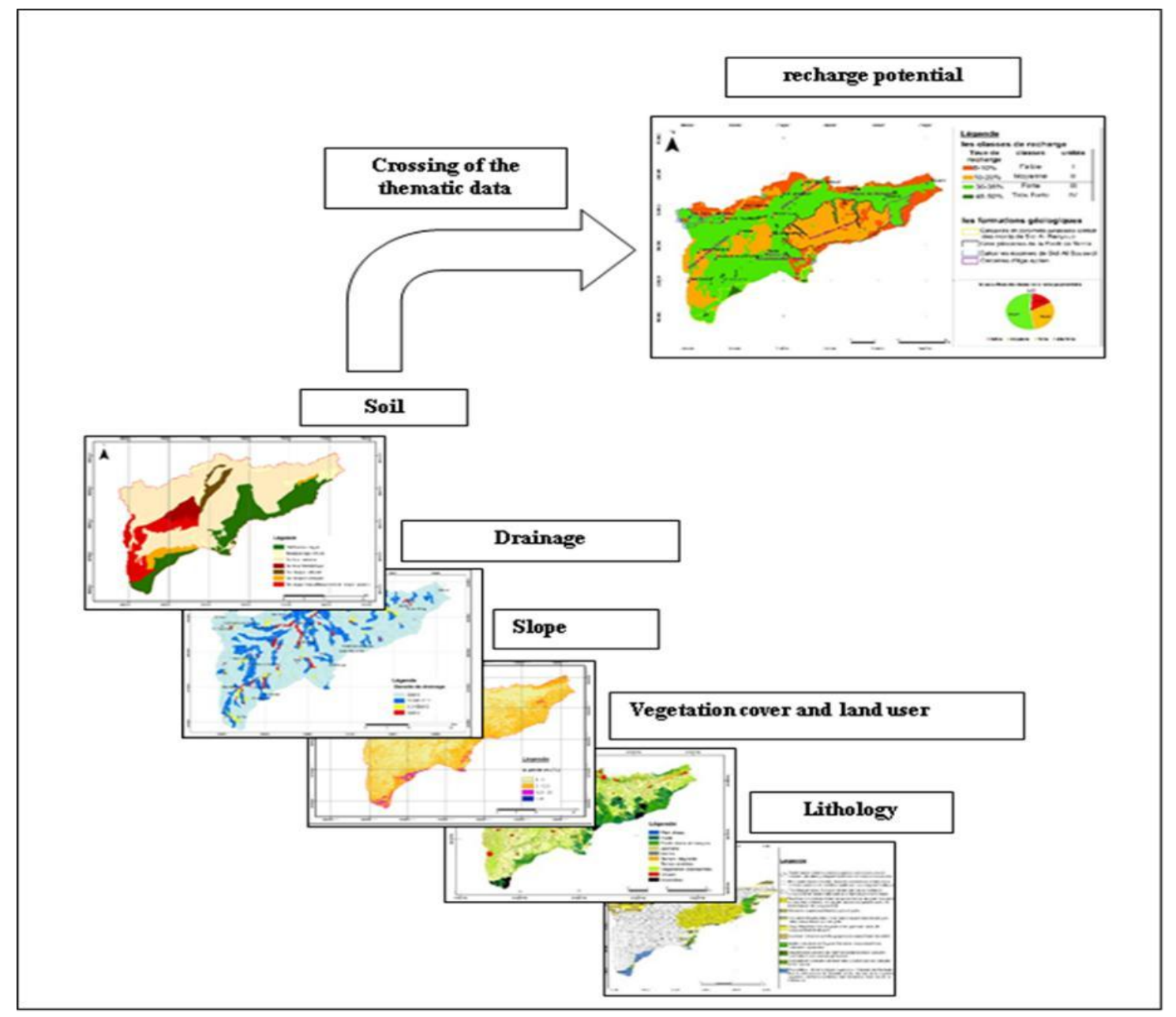

Figure 2: Plan presents the various thematic maps used for Development of recharge potential map 


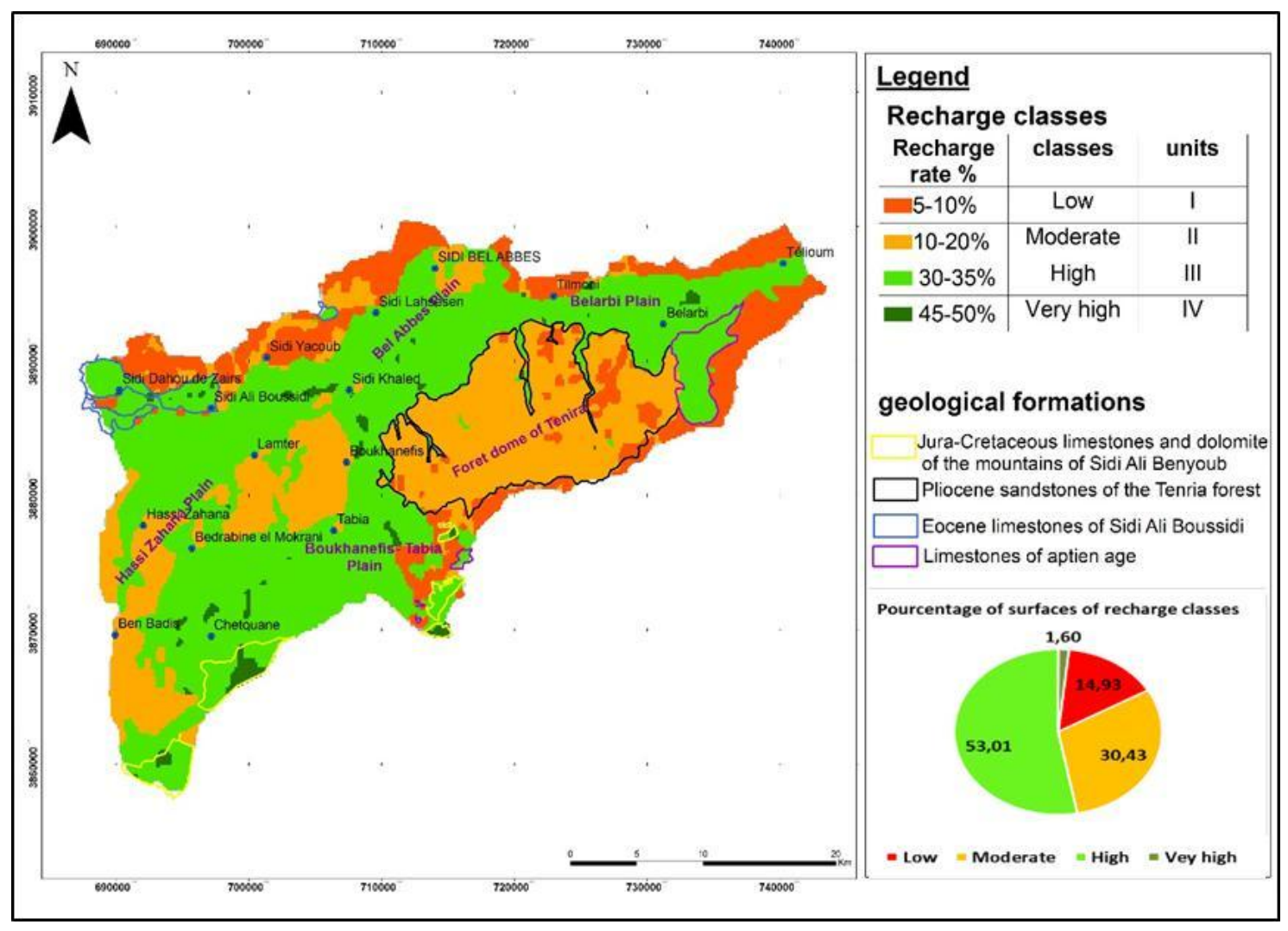

Figure 3: Map of the potential recharge of the Sidi Bel Abbès plain

\section{Estimation of the infiltration (potential recharge)}

To calculate the quantity of infiltrated water, a simplified calculation proposed by the FAO in 1967 (equation 1) [4, 8].

Infiltrated volume $($ Vinf $)=$ Precipitated volume $\times \sum($ Recharge rate $\times \%$ of area $)$

(equation 1)

Precipitated volume $=$ average precipitation $\times$ total area of polygons

(equation 2)

Average precipitation in the study area is $0.33 \mathrm{~m}$.

The total area of the polygons is equal to the sum of the area of polygons on each recharge class as shown in Table 3. The result obtained is about $1073 \mathrm{~km}^{2}$.
Therefore, the precipitated volume calculated by the equation 2 is about 354 $\mathrm{hm}^{3}$.

The sum of dot product between the recharge rate and percentage of polygon area for each recharge class is estimated at $0.24 \%$ (Table 3 ).

Table 3: Method of ca lculating the total aera polygons and $\sum$ ( Recharge rate $\times \%$ of area)

\begin{tabular}{|c|c|c|c|c|}
\hline $\begin{array}{c}\text { Recharge } \\
\text { classes }\end{array}$ & Area $\left(\mathrm{km}^{2}\right)$ & Area( \%) & Recharge rate (\%) & $\begin{array}{c}\text { Recharge rate }(\%) \mathrm{x} \\
\text { Area(\%) }\end{array}$ \\
\hline Low & 160.21 & 14.93 & 7.5 & 0.011240178 \\
\hline Moderate & 326.56 & 30.43 & 15 & 0.045822264 \\
\hline High & 568.76 & 53.01 & 32.5 & 0.172915809 \\
\hline Very high & 17.14 & 1.6 & 47.5 & 0.007615996 \\
\hline & Total $=1073 \mathrm{~km}^{2}$ & & & Total $=0.24 \%$ \\
\hline
\end{tabular}


The infiltrated volume $\left(\mathrm{V}_{\text {inf }}\right)=354 \times 0.24=$ $85 \mathrm{hm}^{3}$ / years.

The infiltrated blade water $=$ Infiltrated volume $\left(\mathrm{m}^{3}\right) /$ total area of the polygons $\left(\mathrm{m}^{2}\right)=$ $0.0792 \mathrm{~m}$.

The infiltrated blade water $\left(\mathrm{BW}_{\text {inf }}\right)$ estimates at $79 \mathrm{~mm} /$ year.

This means that $\mathbf{2 4 \%}$ of the annual average precipitation infiltrates into the plain of the study site.

This infiltration or amount of recharge dis- tributed over the study area as follows:

-15\% in the alluvial plain (wadis and agricultural soils).

-4\% in the Pliocene sandstones of the Tenria forest.

-1\% in Jurassico-Cretaceous limestones and dolomites of Sidi Ali Benyoub, Eocene limestones of Sidi Ali Boussidi.

- 4\% in formations that do not contain a ground water table: Cracked limestones of age Aptien,Oligo-Miocene formation, for mation of Valangien (limestone of Remalia c),Miocene marly and clayey-marly for- mations.

\section{Conclusion}

The obtained results show four descriptive level zones through recharge potential map with a $24 \%$ infiltrated blade water, $79 \mathrm{~mm} / \mathrm{year}$.

The areas of high recharge occupy the major part of the study area. According to the FAO scale, the Sidi Bel Abbes plain is a high re- charge with a rate between $20 \%$ and $30 \%$.

The obtained results could confirmed by measures on the ground made to the factors contributing to the infiltration whose valida- tion of these results could also lead to the definition of new criteria or to modify the obtained results.

This type of map provides information on sites where ground water could renewed under normal rainfall conditions. They can used as prevention against the risk of pollution for better management of the groundwater resource.

\section{References}

[1] Abdou Babay, M.S. Evaluation des ressources en eau souterraines dans le bassin de Dargol (Liptako -Niger), Doctoral Thesis in Engineering Sciences, France, 26-29/265p, 2012.

[2] Aranyossy, J.F. \&Njitchoua R. \&Zuppi G.M. l'apport des isotopes de l'environnement à l'étude de la recharge et la dynamique des aquifères,Publi.Synposium international,Paris, pp 39-54,1998.

[3] Faraoun, F. \& Benabdeli, K. Cartographie et caractérisation physico-chimique des sols de la plaine de Sidi Bel Abbés (Algérie occidentale), Afrique SCIENCE, France, vol. 3, pp1826, 2010.

[4] Halouchine A. \& Boudoukha A. \& Haouchine F.Z. \& Rachid N. Cartographie de la recharge potentielle des aquifères en zones arides, plaine d'Outaya, Biskra, EUROJOURNALS, France, vol. 4, pp 1-13, 2011.

[5] Horton, R.E. ,Erosional development of streams and their drainage basins; Hydrophysical approach to quantitative geomorphology, Bull. Geol. Soc. Am., 56, 275-370, 1945.

[6] Lerner, D.N, Issar, A.S., Simmers, I. ,Groundwater recharge: A guide to understanding and estimating natural recharge. International Contributions to Hydrogeology, 8, Heise, Germany. 1990.

[7] Shaban A., Khawlie M., BouKheir R., Abdallah C.Assessment of road instability along a typical mountainous road using GIS and aerial photos, Lebanon - eastern Mediterranean. Bull Eng GeolEnv 60:93-101,2001

[8] Shaban A. \& Khawlie M.R. \& Abdallah C. Use of remote sensing and GIS to determine recharge potential zones: the case of Occidental Lebanon, Hydogéology journal, Lebanon, ,pp. 433-443, 2006.

[9] Sourisseau, B. \& Al. Carte hydrogéologique de la plaine de Sidi Bel Abbès, Report of the Directorate of Environnemental Studies and Hydraulic Research, Algeria, 1973. 